\title{
POZYTYWNY WIZERUNEK UCZELNI I SAMORZĄDU LOKALNEGO - WSPÓLNA SPRAWA
}

\section{mgr Jan Walczak}

Dolnośląska Wyższa Szkoła Przedsiębiorczości i Techniki w Polkowicach

\section{Wprowadzenie}

W niniejszym artykule autor porusza zagadnienie wizerunku niepublicznej szkoły wyższej w kontekście wizerunku samorządu lokalnego, w obrębie którego uczelni przychodzi funkcjonować oraz wzajemnego wpływu wizerunkowego obu podmiotów na siebie i wynikających z tego korzyści. Dla zobrazowania tematu przywołany zostanie szczególny przykład jednego z najzamożniejszych i najlepiej rozwijających się samorządów w Polsce - Gminy Polkowice, którego władze zdecydowały się w 2002 r., we współpracy z "młodym" powiatem polkowickim, na powołanie własnej uczelni, współfinansowanej w dużej mierze - co stanowi prawdopodobnie ewenement na skalę ogólnopolską - z budżetu samorządu. Dolnośląska Wyższa Szkoła Przedsiębiorczości i Techniki w Polkowicach funkcjonuje na rynku edukacyjnym szkolnictwa wyższego od dekady. Nie pozostaje bez znaczenia dla budowy pozytywnego wizerunku samorządu i dla spajania tożsamości społeczności lokalnej. Pomimo, że naukę w niej podejmują także studenci spoza Polkowic, określa się ją mianem „uczelni samorządowej” czy też „lokalnej”, obok podziału na uczelnie publiczne i niepubliczne, w ramach którego została zgodnie z obowiązującym prawem skategoryzowana². Dla kandydatów na studia zapewne nie jest bez znaczenia pozycja w regionie rozwijających się w szybkim tempie Polkowic, oferujących możliwość studiowania, ale i potencjalne miejsca pracy oraz w dalszej perspektywie atrakcyjne warunki do życia.

Celem artykułu jest próba ukazania w zarysie na przykładzie Polkowic i działającej na ich terenie Dolnośląskiej Wyższej Szkoły Przedsiębiorczości i Techniki znaczenia, jakie może mieć niepubliczna uczelnia dla wzmacniania pozytywnego wizerunku samorządu lokalnego oraz zaprezentowanie zakresu współpracy między szkołą wyższą a samorządem i jej wartości wizerunkowej dla samej uczelni. Temat ze względu na ramy artykułu zostanie ograniczony do najistotniejszych, zdaniem autora, kwestii.

1 Ministerstwo Nauki i Szkolnictwa Wyższego nie posiada danych w tym zakresie.

2 Zob. W. Olszewski, W poszukiwaniu modelu uczelni lokalnej-studium przypadku, [w:] Społeczności lokalne. Problemy-zmiany-rozwój, praca zbiorowa pod red. M. Adamczyka, A. Chmiela, Wydawnictwo DWSPiT w Polkowicach, Polkowice 2012, s. 57. 
Rozwój gospodarki rynkowej po 1990 r. spowodował, że zarówno edukację, jak i miasto oraz region zaczęto postrzegać w kategoriach komercyjnych. W chcących rozwijać się uczelniach, jak i samorządach, środek ciężkości przeniósł się z "administrowania” na "sprzedaż produktu”. Co więcej, na dostarczenie odbiorcom oferty, która powinna być postrzegana przez nich jako unikalna³. W przypadku szkół wyższych zaczęto konkurować o pozyskanie studentów, w przypadku miast i regionów m.in. o inwestorów krajowych i zagranicznych, a także turystów. Dla odniesienia sukcesu rynkowego niezbędne okazało się komunikowanie z obecnymi i potencjalnymi klientami, co w efekcie ma spowodować ukształtowanie się określonego wizerunku w bezpośrednim otoczeniu

Konsekwentna dbałość o wizerunek uczelni i samorządu w dzisiejszej dobie to nie tylko kwestia prestiżu i satysfakcji ich władz, ale także tzw. „być albo nie być” w obliczu niżu demograficznego i rosnącej konkurencji o pozyskiwanie studentów, czy też inwestorów krajowych i zagranicznych, w przypadku władz samorządowych.

Idealną sytuacją jest, kiedy pozytywny wizerunek szkoły wyższej jest skorelowany z pozytywnie postrzeganym obrazem miasta np. w wyobrażeniu kandydatów na studentów, którzy zamieszkają tam, po podjęciu decyzji, na czas studiów lub też będą dojeżdżać na naukę. Sytuacją mniej pożądaną jest ta, kiedy image 5 miasta i image uczelni nie są spójne i budzą zupełnie odmienne emocje - uczelnia wydaje się kształcić na wysokim poziomie, zaś miasto, w którym funkcjonuje szkoła wyższa nie spełnia oczekiwań kandydata na studia lub nie budzi skojarzeń ani emocji. Miasto o znakomitym wizerunku może też dysponować położoną na jego terytorium uczelnią posiadającą niepochlebny image lub niewyróżniającą się w świadomości kandydata na studia niczym szczególnym. Negatywny lub pozytywny czy neutralny wizerunek jednego z nich - miasta bądź uczelni - może być decydujący dla wyboru lub rezygnacji z podjęcia związku z placówką naukową na czas studiów, a z regionem być może na całe życie. Dlatego zasadniczą kwestią jest wyróżnienie się na tle innych podobnych podmiotów - wskazywanie cech charakterystycznych i odróżniających. Taką konieczność akcentuje obecnie sprawujący urząd burmistrz Polkowic W. Wabik: „(...) DWSPiT w Polkowicach sprzyja rozwojowi miasta i całej gminy. Obserwuję, że wraz z upływem lat wciąż zmieniające się oczekiwania samorządu pod adresem uczelni, są nadal wyraźnie artykułowane i odczuwalne w różnych przejawach funkcjonowania miasta. Postępujemy tak z autentycznym przekonaniem. Tym bardziej, iż cel jest niezmienny - nadążać za wymogami współczesnych czasów, pozytywnie wyróżniać się na coraz bardziej konkurencyjnym rynku marek i idei".

3 R. Kłeczek, W. Kowal, J. Woźniczka, Strategiczne planowanie marketingowe, Warszawa 1999, s. 22.

4 A. Stanowicka-Traczyk, Kształtowanie wizerunku miasta na przykładzie miast polskich, Bydgoszcz-Olsztyn 2008 , s. 13.

5 Image - ang. pozytywny wizerunek.

6 Rozmowa $z$ aktualnie sprawujacym urząd burmistrzem Polkowic W. Wabikiem przeprowadzona przez

J. Walczaka w 2012 r. 


\section{Pozytywny wizerunek uczelni}

Jak uważa E. M. Cenker, wizerunek instytucji czy przedsiębiorstwa jest swoistym obrazem w świadomości osób, które mają z nią kontakt bezpośredni lub pośredni - mowa zatem o klientach, czyli studentach - jak i innych uczestnikach rynku - obserwatorach utrwalających opinię o szkole wyższej. Wizerunek jest czymś zewnętrznym, na co uczelnia może jedynie starać się mieć wpływ i modelować go według potrzeb . Wizerunek można traktować więc jako kategorię poznawczą, obejmującą:

- w warstwie poznawczej - wiedzę, przekonanie, opinie;

- w warstwie emocjonalnej - odczucia, oceny wartościujące;

- w warstwie behawioralnej - określa skłonność do zachowań, które mogą przekształcić się w zamiar „zakupu” lub rezygnację z niego ${ }^{8}$.

Kreowanie zamierzonego wizerunku uczelni ma na celu doprowadzenie do wysokiej jego wyrazistości tak, iż będzie możliwa łatwa i szybka identyfikacja placówki edukacyjnej. Jest to zadanie stosunkowo trudne, ponieważ na rynku uczelni niepublicznych mamy do czynienia, jak zaznacza B. Iwankiewicz-Rak, z podobnie sformułowanymi nazwami szkół, wydziałów, kierunków, dalej programów nauczania oraz kierunków studiów. Kształtowanie wizerunku należy odebrać jako proces wymagający skoordynowanej kampanii, nakierowany w taki sposób, aby niematerialnie pojmowane, i dość podobne wszędzie, usługi edukacyjne zmaterializowały się poprzez m.in. kulturę działania, relacje zachodzące w uczelni między studentem a wykładowcą czy precyzyjnie sformułowaną misję szkoły wyższej - które to mogą wyróżniać na tle innych ${ }^{9}$. Wizerunek charakteryzuje się dynamiką i ulega zmianie wraz ze zmianą poglądów i upodobań otoczenia. Nie zawsze odzwierciedla rzeczywistość, ponieważ powstaje w wyniku procesu nacechowanego subiektywizmem. Ważną rolę dla kształtowania wizerunku odgrywa tożsamość, która oznacza świadomość tego, kim się jest. Warto zaznaczyć, że tożsamość nie jest lustrzanym odbiciem wizerunku, gdyż wizerunek jest końcowym obrazem zweryfikowanym przez wiele czynników ${ }^{10}$.

Budowaniu wizerunku, także uczelni, służy, public relations, który jest rozumiany przez autora za T. Gobanem Klasem jako „funkcja zarządzania, która nawiązuje i podtrzymuje wzajemne korzystne stosunki między instytucjami oraz grupami, od których zależy ich sukces lub klęska"11.

Wizerunek uczelni, jak i każdej innej instytucji, nie jest jednorodny, a na jego złożoność wpływają przekonania, wrażenia, myśli, wyobrażenia, emocje jednostki lub grupy osób na temat danego obiektu, którym może być uczelnia, wydział, kierunek studiów. Na wielowymiarowy wizerunek szkoły można spojrzeć zatem z wielorakiej perspektywy. Wizerunek uczelni może być kreowany jako image: pracodawcy, twórcy kultury, podmiotu wspieranego finansowo, autorytetu moralnego, nauczyciela czy inwestora ${ }^{12}$.

7 E. M. Cenker, Public relations, Poznań 2007, s. 42.

8 A. Stanowicka-Traczyk, Kształtowanie..., op. cit., s. 16-17.

9 B. Iwankiewicz-Rak, Public relations w instytucjach publicznych i organizacjach pozarzadowych, [w:] Public relations. Znaczenie społeczne i kierunki rozwoju, praca zbiorowa pod red. J. Olędzkiego, D. Tworzydło, Warszawa 2007, s. 94. 10 A. Stanowicka-Traczyk, Ksztattowanie..., op. cit., s. 21.

11 B. Iwankiewicz-Rak, Zarządzanie marketingowe szkoła wyższą, [w:] Marketing szkół wyższych, praca zbiorowa pod red. G. Nowaczyk, M. Kolasińskiego, Poznań 2004, s. 54. Zob. T. Goban Klas, Public relations czyli promocja reputacji, Warszawa 1997, s. 26.

12 Ibidem, s. 55. 
Integracja i koordynacja budowania wizerunku we wszystkich zakresach służy kształtowaniu całkowitego wizerunku szkoły wyższej.

Dobry wizerunek firmy może pełnić funkcje, które dostosowując do potrzeb uczelni można określić w sposób następujący:

- zjednuje opinię publiczną do marki szkoły wyższej;

- usuwa anonimowość między uczelnią a odbiorcą;

- ułatwia wzajemne porozumienie;

- sprzyja wytworzeniu korzystnego nastawienia do uczelni i jej poczynań, a także wpływa na poczucie akceptacji ${ }^{13}$.

Dla kształtowana wizerunku, jak uważa E. M. Cenker, niebagatelne znacznie mają image całej branży, tu edukacyjnej, czyli reputacja uczelni niepublicznych lub publicznych. Co więcej, wpływ na wizerunek firmy lub produktu ma także image przestrzeni terytorialnej, w którym wytworzono produkt - tu rozumiany jako oferta edukacyjna.

\section{Pozytywny wizerunek samorządu}

Można sądzić, że istnieje zależność między wizerunkiem terytorialnym a wizerunkiem firmy czy też produktu. Skojarzenia wiążą kraj z typem produktu: Włochy - spaghetti, pizza, ale i ze sposobem wykonania: Chiny - produkty, jak przyjęło się uważać, nietrwałe, niesolidne wykonane, co niekoniecznie musi być zgodne z prawdą pod warunkiem utrzymania wysokiego poziomu kontroli jakości w dobrze zorganizowanej firmie. Postrzeganie obszaru terytorialnego można zmienić poprzez kampanie promocyjne nakierowane nie tylko na produkt, ale też na wizerunek obszaru, z którego pochodzi ${ }^{14}$.

Od chwili transformacji ustrojowej administracja samorządowa nabrała zupełnie nowego znaczenia, a jej funkcjonowanie zdeterminowała, jak i w przypadku szkół wyższych, gospodarka rynkowa. Tyle, że w tym przypadku decydującą rolę miały szczególnie takie przesłanki jak decentralizacja decyzji i dyspozycji funduszami publicznymi oraz wyraźna możliwość artykulacji interesów lokalnych na gruncie ekonomicznym i społecznym ${ }^{15}$. Dzięki temu, pojawiła się konieczność rozwoju konkurencyjności samorządów i regionów o korzyści zewnętrzne w postaci różnych grup kapitału: finansowego, rzeczowego, społecznego, intelektualnego (tu: szkoły wyższe). Przyczynia się to do wzrostu dochodów, zatrudnienia, zwiększenia atrakcyjności życia obywateli i prowadzenia działalności gospodarczej. W przypadku gminy wpływ na jej konkurencyjność na tle innych samorządów determinuje: projekt urbanistyczny, infrastruktura społeczna i techniczna, świadczone usługi - w tym edukacyjne na różnych poziomach kształcenia - atrakcje turystyczne, przyrodnicze oraz struktura społeczno-demograficzna i zawodowa. Te elementy wykorzystywane są w budowie strategii przemian, które pozwalają zaplanować rozwój samorządu pod kątem rywalizacji między gminami. Samorządy konkurują głównie o inwestycje zagraniczne, turystów i wykwalifikowane 13 E. M. Cenker, Public..., op. cit., s. 42.

14 Ibidem, s. 45.

15 B. Iwankiewicz-Rak, Public..., op. cit., s. 100. Zob. też: E. Zeman-Miszewska, Kreowanie konkurencyjności i regionów przez samorządy terytorialne, [w:] Marketing terytorialny: możliwości aplikacji, kierunki rozwoju, praca zbiorowa pod. red. H. Szulce, M. Florek, Poznań 2005, s. 135. 
kadry. Kształtowanie wizerunku gminy kompetentnej w różnorakich zakresach jest skierowane do tzw. publiczności wewnętrznej oraz zewnętrznej. Pierwszą grupę tworzą: mieszkańcy, przedsiębiorstwa, instytucje lokalne, organizacje pozarządowe itp. W skład publiczności zewnętrznej wchodzą m.in.: inwestorzy, turyści, podmioty rynku finansowego, przedsiębiorcy globalni, studenci spoza gminy, absolwenci spoza gminy i zapewne kandydaci na studia. Kluczową kwestią w przypadku samorządu, podobnie jak w przypadku uczelni, jest takie wykreowanie wizerunku publicznego, które pozwoli na wyakcentowanie wyrazistości, indywidualizmu, na polach ważnych dla środowiska społecznego i gospodarczego, umożliwiających jednoznaczną identyfikację na tle konkurencji ${ }^{16}$.

W tym celu niezbędne okazuje się określenie tzw. produktu terytorialnego (nazywanego też megaproduktem $)^{17}$, który jest rozumiany jako składowa wielu elementów - subproduktów. Te z kolei mogą być odwzorowywane przez konkurencyjne gminy; z jednym wyjątkiem - subproduktu kulturowego, specyficznego i wyjątkowego, związanego z miejscem wytwarzania i oferowania. Obok tego wyjątkowego subproduktu możliwe do zbudowania są także inne subprodukty, np.: socjalny, inwestycyjny, turystyczny, publiczny, targowo-wystawienniczy, handlowo-usługowy, mieszkaniowy, rekreacyjno sportowy, a także istotny w tym wypadku oświatowo-kulturalny, zwany też produktem oświatowo-społecznym. Jego zasadniczą składową tworzą m.in.: szkoły, uczelnie i inne placówki edukacyjne istniejące w danym mieście, poziom wykształcenia mieszkańców, kwalifikacje i umiejętności potencjalnych i obecnych pracowników firm i instytucji itp. ${ }^{18}$.

Wykreowane wizerunek i tożsamość gminy są wykorzystane przez władzę samorządową, a ich adresatami są społeczności wewnętrzna (lokalne) i zewnętrzne ${ }^{19}$. Jako pozytywny obraz w ludzkiej świadomości służą one:

- identyfikacji wyróżniających cech na tle konkurencji;

- integrowaniu społeczności lokalnej i budowaniu lojalności;

- prezentowaniu wartości materialnych i ideowych dla różnych grup interesariuszy;

- zdobywaniu poparcia społecznego i jego utrwalania dla wizji i wyznaczonych kierunków rozwoju gminy;

- utrzymywaniu władzy przez wskazywanie korzyści dla mieszkańców.

Polkowice i subregion polkowicki stawały kilkakrotnie przed koniecznością przebudowy elementów wizerunku samorządu w ciągu minionych dwóch dekad w poszczególnych polach subproduktów produktu terytorialnego. Zarówno w momencie ukonstytuowania samorządnych gmin na początku lat 90, jak i w chwili utworzenia samorządu powiatowego w mieście w 1999 r., ale także kiedy doszło do rozwoju gospodarczego (tworzenie Legnickiej Specjalnej Strefy Ekonomicznej, negocjacje z inwestorami) i w innych pozytywnych momentach rozwoju polkowickiego samorządu - w tym uruchomienia w $2002 \mathrm{r}$. uczelni - Dolnośląskiej Wyższej Szkoły Przedsiębiorczości i Techniki w Polkowicach ${ }^{20}$. Ukształtowany 16 Ibidem, s. 100.

17 Zob. A. Stanowicka-Traczyk, Kształtowanie..., op. cit., s. 105.

18 B. Iwankiewicz-Rak, Public..., op. cit., s. 101. Zob. też: A. Stanowicka-Traczyk, Ksztaltowanie..., op. cit., s. 105.

19 Ibidem. s. 101.

20 Ibidem, s. 102. 
w przeszłości negatywny, jak można sądzić na podstawie rozmów przeprowadzonych z polkowiczanami przez autora, obraz miasteczka górniczego został skutecznie zastąpiony nowym pozytywnym wizerunkiem, w okolicznościach gospodarki rynkowej i sprzyjających warunków budżetowych ${ }^{21}$.

\section{Polkowice - 20 lat budowy mocnego wizerunku od podstaw}

Polkowice (woj. dolnośląskie) dopiero w latach 90. ubiegłego wieku stały się centrum subregionu polkowickiego i z czasem centrum życia samorządowego - od 1999 r. zlokalizowano tu po raz pierwszy w historii siedzibę starostwa powiatowego. Stało się to wyłącznie dzięki determinacji władz miejskich Polkowic, które nie bez trudności i skomplikowanych zabiegów dążyły do utworzenia powiatu polkowickiego. Moment był w rzeczywistości przełomowy, ponieważ Polkowice pod względem administracyjnym naprzemian związane były od zawsze z pobliskim Głogowem bądź też Lubinem²2. Jeszcze na początku lat 90. Polkowice nazywano, jak określają to jego mieszkańcy "górniczą sypialnią”, „zaściankiem”23. Jako miasto zostały przebudowane i rozbudowane w latach 70. po to, by zapewnić miejsce do życia kilku tysiącom górników i ich rodzinom, jednak władzom centralnym nie zależało na jego rozwoju. Mimo tych mało pozytywnych opinii warto zaznaczyć jednocześnie, że w Polkowicach w okresie PRL żyło się lepiej niż w innych miastach Dolnego Śląska. Z tego względu, że przemysł górniczy i jego pracownicy byli traktowani priorytetowo przez władze centralne. Odzwierciedlało się to np. w lepszym zaopatrzeniu sklepów24. Polkowiczanie stanowili ludność napływową z wielu części Polski (osiedlenia powojenne i osiedlania po odkryciu złóż rud miedzi), a ich tożsamość związana z miastem nie była zbyt silna, co można wywnioskować z przeprowadzonych wywiadów z polkowiczanami. Miasto przed 1990 r. wyglądało mało zachęcająco - było szare, pełne blokowisk, zaprojektowane bez większego wysiłku architektów. Przez lata, mimo, że pod powierzchnią Gminy Polkowice zlokalizowana była większość kopalni rud miedzi należących do Kombinatu Górniczo-Hutniczego Miedzi (dziś koncern KGHM Polska Miedź SA), miasto nie czerpało z bogactw naturalnych właściwie żadnych korzyści, a strumienie zysków płynęły wprost do budżetu państwa ${ }^{25}$. Dopiero początek lat 90. i Ustawa o samorządzie gminnym z dnia 8 marca 1990 r. ${ }^{26}$ przyniosły zmiany. Z roku na rok budżet Polkowic zwiększył się trzykrotnie (1990 r. i 1991 r.) a władze samorządowe stanęły przed wyzwaniem, jakim było odmienienie miasta pod każdym względem i nadrobienie zaległości. Rada Miasta stanęła przed dylematem jak rozplanować nowy, wysoki budżet. W latach 90. miasteczko, nazywane "achillesową piętą Zagłębia Miedziowego 27" zyskało zupełnie nowy obraz i zasłynęło w Polsce już nie tylko z wydobycia rud miedzi, ale również ze spektakularnych inwestycji; stało się jedną z pierwszych miejscowości w kraju posiadających park wodny - Aquapark (dziś pod nazwą Aquapark Polkowice -

21 Rozmowy z mieszkańcami Polkowic zostały przeprowadzone przez J. Walczaka w 2011 i 2012 r. na potrzeby monografi:

J. Tyszkiewicz (red.), Polkowice - historia wspótczesna (1945-2010), Wydawnictwo DWSPiT w Polkowicach,

Polkowice 2012 r.

22 A. Szydłowska-Szczecińska, Polkowice. Dwadzieścia niezwyklych lat, Chroma, Żary 2010, s. 53-70.

23 Rozmowy z mieszkańcami Polkowic - J. Walczak. Zob. też. A. Szydłowska-Szczecińska, Polkowice..., op. cit., s. 9.

24 Rozmowa $z$ ostatnim naczelnikiem Polkowic B. Kocwa przeprowadzona przez J. Walczaka $w 2011 \mathrm{r}$.

$25 \mathrm{Na}$ podst. rozmowy autora $z$ B. Kocwą. J. Walczak, 2011.

26 Ustawa o samorzadzie gminnym z dnia 8 marca 1990 r., Dz. U. 2001.142.1591.

27 A. Szydłowska-Szczecińska, Polkowice, Dwadzieścia niezwyklych lat, Polkowice 2010, s. 34. 
Regionalne Centrum Rekreacyjno-Rehabilitacyjne SA). Równocześnie ogromne wrażenie na obserwatorach, także tych z zewnątrz, zrobiła inwestycja polegająca na wyburzeniu i odbudowaniu od podstaw zabudowy rynku i Starego Miasta zgodnie z wytycznymi konserwatora zabytków, a także, co można określić jednym z najważniejszych polkowickich osiągnięć gospodarczych, utworzenie podstrefy ekonomicznej w Polkowicach - części Legnickiej Specjalnej Strefy Ekonomicznej - która zapełniła się w ciągu kilku lat ważnymi inwestorami, takimi jak: Volkswagen Motor Polska sp. z o. o., Sitech sp. z o. o., TCM Polska sp. z o. o., Sanden sp. z o. o., Royal Europa sp. z o. o. czy NG2 SA (właściciel takich marek jak: CCC, Boti, Quazi). O sukcesach można też mówić w zakresie rozwoju życia kulturalnego (m.in. Polkowickie Dni Teatru) oraz sportowego (np. drużyny ekstraklasy kobiet w koszykówce - CCC Polkowice, tenisie stołowym - MKSTS DWSPiT Polkowice czy podnoszeniu ciężarów mężczyzn - KPC Górnik Polkowice). Aktualnie władze samorządowe dążą do zmniejszenia zależności od KGHM, zdając sobie sprawę, że dochodowe złoża rud miedzi z czasem mogą ulec wyczerpaniu.

Strategia Rozwoju Zrównoważonego Gminy Polkowice na lata 2010-2015 zakłada, że gospodarka Gminy Polkowice będzie ulegać polifunkcjonalizacji, co oznacza, że KGHM Polska Miedź SA stopniowo miałby tracić wiodącą rolę dla mieszkańców Polkowic i samorządu. Do tego stanu władze gminy starają się od lat przygotowywać. Zdaniem autora strategii, Andrzeja Sztando, rozwój alternatywnych form działalności gospodarczej będzie dotyczył przede wszystkim przemysłu, budownictwa, handlu i usług. Nie bez znaczenia pozostaną szkolnictwo, nauka, rolnictwo i usługi niekomercyjne ${ }^{28}$. Takie zaplanowanie form działalności gospodarczej świadczy o woli budowania przez samorząd konkretnego produktu terytorialnego, w którym istotną rolę ma odgrywać także polkowicka uczelnia.

Jedną z inicjatyw, jak się wydaje, mającą spowodować zmianę charakteru miasta było utworzenie przez samorząd szkoły wyższej, której poświęcone zostaną kolejne akapity.

Budżet Polkowic należy obecnie do najzasobniejszych nie tylko na Dolnym Śląsku, ale także w Polsce. Kryzys gospodarczy zdecydowanie nie dotknął tego rejonu kraju. Rankingi najbogatszych samorządów lokują Polkowice na trzecim miejscu w kraju po Kleszczowie i Nowym Warpnie ${ }^{29}$. Budżet dwudziestokilkutysięcznych Polkowic porównywalny jest z rocznym budżetem trzykrotnie większych sąsiednich miast Lubina i Głogowa - dwóch ważnych obok Legnicy miejscowości Zagłębia Miedziowego.

Dla porównania warto przywołać wysokość planowanych tam budżetów na rok 2011 (Polkowice 202,4 $\mathrm{mln} \mathrm{z}^{30}$ ): blisko siedemdziesięciotysięcznego Głogowa - 183,3 mln zł ${ }^{31}$ i siedemdziesięciopięciotysięcznego Lubina - 229,4 mln $\mathrm{z}^{32}$.

28 A. Sztando, Strategia rozwoju zrównoważonego Gminy Polkowice na lata 2010-2015, Polkowice 2010, s. 65. 20120, U. nr XXXIII/336/10 Rady Miejskiej Polkowic z dn. 28 czerwca 2010 r.

29 P. Włóczyk, Rajskie życie w bogatych gminach, Prawo-Rzeczpospolita, 27.07.2011 http://prawo.rp.pl/artykul/693309.html, dostęp 18.10.2012.

30 U. nr VI/47/11 Rady Miejskiej w Polkowicach z dnia 3 lutego 2011 r. w sprawie budżetu Gminy na rok 2011. http://www. bip.ug.polkowice.pl/doc/2007/VI-47-11.pdf, dostęp 15.10.2012.

31 U. nr VI/26/2011 Rady Miejskiej w Głogowie z dnia 13 stycznia 2011 r.w sprawie uchwalenia budżetu Gminy Miejskiej Głogów na rok 2011. http://sbip.pl/nglogow/site/pl/search, dostęp 15.10.2012.

32 U. nr IV/24/11 Rady Miejskiej w Lubinie z dnia 11 stycznia 2011 r. w sprawie budżetu miasta Lubina na rok 2011. http://www.um.lubin.pl/dokument.php?iddok=1580\&dstr=1\&txt=budżet 2011, dostęp 15.10.2012. 
Zmiana wizerunkowa miasta i budowanie zupełnie nowego oblicza Polkowic możliwe jest dzięki znacznym przychodom budżetowym, które we wrześniu 2012 r. przekroczyły w sposób istotny planowany budżet na ten rok. Po korekcie budżetu po stronie dochodów wykazano kwotę $278 \mathrm{mln}$ zł, zaś po stronie wydatków - 253 mln zł. Krystyna Kozłowska, skarbnik Gminy Polkowice oświadczyła w mediach, że „zmiany wynikają głównie z większego podatku dochodowego od osób prawnych, w tym przede wszystkim KGHM. Zaplanowane udziały gminy w tym podatku to $100 \mathrm{mln}$ zł. KGHM ma dobrą kondycję finansową i to sprawia, że podatek jest wysoki .Tegoroczny budżet jest naprawdę rekordowy. Jeszcze nigdy nie mieliśmy takiej kwoty po stronie dochodów"33.

Przełom w rozwoju samorządu, jaki dokonał się w ciągu ostatnich 20 lat, wiąże się ze zmianą sposobu postrzegania mało atrakcyjnych jeszcze na początku lat $90 .^{34}$ Polkowic, które dziś przez mieszkańców sąsiednich miast uznawane są za doskonałe miejsce do życia i stawiane są za wzór, głównie ze względu na dostępność pracy w polkowickiej części Specjalnej Legnickiej Strefy Ekonomicznej oraz kopalniach i innych zakładach należących do KGHM Polska Miedź SA. W ciągu ostatnich dwóch dekad zmieniła się także jakość życia mieszkańców Polkowic dzięki poprawiającej się estetyzacji miasta, regularnie prowadzonych remontach infrastruktury, rewitalizacji budynków, a także budowaniu nowych osiedli i wytyczaniu kolejnych terenów, które pozwalają na rozbudowę miasta. Znaczną troską miasto otacza polkowiczan pod względem socjalnym oferując m.in. programy prozdrowotne w pełni finansowane przez samorząd. Wszystkie modernizacje i zmiany wprowadzane są z dbałością o najwyższą jakość i wysoki poziom zadowolenia polkowiczan. O trosce gminy w tej kwestii świadczy wdrożenie prestiżowych certyfikatów jakości obsługi klienta w Urzędzie Gminy Polkowice, jako jednym z pierwszych samorządów w Polsce ${ }^{35}$.

Polkowice zyskały nowoczesny wizerunek, dynamicznie rozwijającego się miasta, gdzie światowe rozwiązania są stosowane na porządku dziennym: ogólnodostępny Internet bezprzewodowy oraz tzw. kioski internetowe na terenie miasta, latarnie drogowe wykorzystujące energię solarną, czy przystanki autobusowe zasilane takim rodzajem energii to sygnalne przykłady innowacyjnościj6.

Hasło promocyjne gminy, które jest na stałe połączone z oficjalnym atrakcyjnym logotypem brzmi: „Polkowice - Gmina na przyszłość" w pełni odzwierciedla charakter rozwijającego się miasta, do którego przylgnęła nazwa „Supermiasteczko”, będąca tytułem, nadanym, pośród innych wyróżnień, dla Polkowic przez dziennik „Rzeczpospolita” (2001, 2003, 2004). Polkowiczanie o swoim mieście mówią w sposób żartobliwy, określając je „Polkoriko", co można rozumieć jako werbalne odzwierciedlenie poziomu satysfakcji37.

Mieszkańcy Polkowic czują się w swoim mieście coraz lepiej. O ile na początku lat 90. mówili o górniczym mieście z dezaprobatą i czuli się w nim nieswojo ${ }^{38}$, badanie opinii mieszkańców zrealizowane

\footnotetext{
33 Mat, Kasa pęka w szwach, Radio Elka Głogów-Lubin-Polkowice-Legnica, 3.10.2012, http://miedziowe.pl/content/ view/59511/81/, dostęp 15.10.2012.

34 Zob. A. Szydłowska-Szczecińska, Polkowice..., op. cit., s. 39.

35 Ibidem, s. 98.

36 Tom, Wiaty z solarami, „Express Lubin-Głogów-Polkowice”, 4.11.2009.

37 Wywiady z mieszkańcami Polkowic - J. Walczak.

38 Wyniki konkursu na wiersz o Polkowicach, „Gazeta Polkowicka”, czerwiec-lipiec 1991, nr 6-7/9-10.
} 
w 2009 r. na zlecenie Gminy Polkowice dostarcza zgoła odmiennych wyników ${ }^{39}$. Na ich podstawie można wnioskować, że w Gminie Polkowice żyje się dobrze, a poziom życia w tym regionie jest wyższy niż w innych miejscach - taką opinię podziela blisko 80 proc. badanych. Analogiczna grupa jest dumna ze swojego regionu, ponieważ: miasto się rozwija, bogaci się i przybywa miejsc pracy; jest atrakcyjnie położone, zadbane i ładne; mieszka się w nim dobrze; panuje przyjemna atmosfera ${ }^{40}$. Co trzeci badany uważał, że poziom życia jest dużo wyższy niż w innych miejscach ${ }^{41}$.

Małgorzata Skórska i Jan Wawrzyniak dbający po roku 1990 o wizerunek Gminy Polkowice tak mówili w jednym z wywiadów dla branżowego serwisu informacyjnego PRoto Public Relations: „Informacyjny i wizerunkowy przekaz, kierowany do każdej z tych grup [mieszkańców, inwestorów, turystów - red.] musi być i jest zróżnicowany w formie i treści. Wspólnym elementem jest na pewno logo Polkowic z (...) przesłaniem (...). Przygotowujemy materiały informacyjne, oferty gospodarcze, prezentacje. Pojawiają się liczne publikacje w mediach. Dbamy o stałą aktualizację stron internetowych. Szczególną wagę przykładamy jednak do komunikacji z mieszkańcami. Gmina wydaje dwutygodnik ["Gazeta Polkowicka" - red.], który informuje o wszystkich przedsięwzięciach Rady Miasta i urzędu, ale również opisuje życie kulturalne i sportowe Polkowic, zajmuje się sprawami mieszkańców. „Gazeta Polkowicka” ma swoją internetową edycję na stronach www.polkowice.pl. We współpracy z gminą powstaje program lokalnej telewizji kablowej" ${ }^{42 "}$.

Warto zaznaczyć, że Gmina Polkowice uzyskała w ostatnich latach wśród nagród za inwestycje i rozwój także wyróżnienia za promocję wizerunku nadawane przez Polską Agencję Prasową, uzyskując tytuł „Najaktywniejsza Jednostka Samorządu Terytorialnego"43.

Działania promocyjne prowadzone przez Gminę Polkowice od dwóch dekad należą do najaktywniejszych w regionie, co zapewne jest związane ze środkami budżetowymi, będącymi w dyspozycji samorządu, jednak dziś można ocenić z perspektywy czasu, że przyniosły one pożądane rezultaty. Mieszkańcy okolicznych miejscowości, jak można sądzić, spoglądają na polkowicki „dobrobyt” z niekrytą zazdrością, co do której są realne powody. Potencjał jakim dziś dysponują Polkowice sprawia, że miasto przyciąga również młodych ludzi, którzy w trudnych czasach kryzysu szukają perspektyw i pomysłu na dorosłe życie, wybierając studia w Polkowicach, chcąc tutaj podjąć pracę i zamieszkać.

\section{Dolnośląska Wyższa Szkoła Przedsiębiorczości i Techniki w Polkowicach - - „uczelnia samorządowa”}

Pierwsze spotkanie organizacyjne dotyczące powołania uczelni przez władze Polkowic odbyło się w czerwcu 1998 r. w polkowickim Zespole Szkół. Planowano, że zajęcia będą prowadzone przez pracow-

\footnotetext{
39 Badanie opinii mieszkańców Gminy Polkowice. Raport z badania ilościowego zrealizowanego na zlecenie Urzędu Gminy Polkowice. Opracowanie: wrzesień 2009, Biur Badań Społecznych Obserwator.

40 Ibidem, s. 12.

41 Ibidem, s. 13.

425 pytań do Małgorzaty Skórskiej i Jana Wawrzyniaka dbających o wizerunek Gminy Polkowice, http://www.proto.pl/archiwum/5pytan2/info?trackName=PR_5pytan_question\&maxrec=30\&type_id=eqむid=25, dostęp 2.10.2012. 43 http://www.polkowice.pl/strona/39/Sukcesy\%20gminy\%20Polkowice, dostęp 4.10.2012.
} 
ników naukowych z Poznania, Wrocławia i Częstochowy. Przewidywano wówczas dwa kierunki studiów: administrację i zarządzanie ze specjalnością samorządową oraz stosunki międzynarodowe ze specjalnością związaną z integracją europejską ${ }^{44}$. Pomysł utworzenia uczelni był inicjatywą wieloletniego burmistrza dla Polkowic Emiliana Stańczyszyna, który tak wspomina inspirację do działania:„Będąc studentem śpiewałem w Chórze Górniczym Politechniki Wrocławskiej. To był znakomity chór, który koncertował na całym świecie. Dzięki temu widziałem wiele brytyjskich i amerykańskich miast i miasteczek akademickich, które wspaniale rozwinęły się właśnie dlatego, że powstała tam kiedyś uczelnia. To zapadło bardzo mocno w mojej świadomości. Chciałbym, aby nasza młoda uczelnia wyższa coraz bardziej kojarzona była z nowoczesnym motorem wspierającym rozwój Polkowic"45.

We wrześniu 1999 r. powołano spółkę ZamPol SA, która miała się zająć organizacją szkoły wyższej w Polkowicach ${ }^{46}$, zaś w grudniu tego roku, złożono stosowny wniosek w ministerstwie. 51 proc. udziałów w spółce, która miała zarządzać szkołą uzyskali wykładowcy, pozostałą część Gmina Polkowice i Powiat Polkowicki. Z czasem większościowe udziały przejęła Gmina Polkowice. Zdecydowano o uruchomieniu dwóch kierunków: stosunki międzynarodowe oraz informatyka na poziomach licencjackim i inżynierskim $^{47}$.

Po trzech latach starań, w styczniu 2002 r. minister wydał zgodę na uruchomienie w Polkowicach szkoły wyższej - Dolnośląskiej Wyższej Szkoły Przedsiębiorczości i Techniki ${ }^{48}$. Była to pierwsza uczelnia, która powstała w małej miejscowości na Dolnym Śląsku. Budżet szkoły tworzyły dotacje samorządowe gminy i powiatu ${ }^{49}$.

Na stanowisko pierwszego rektora został powołany prof. zw. dr hab. Wacław Kasprzak, były rektor Politechniki Wrocławskiej. Kadra naukowa pochodziła z uczelni wrocławskich, poznańskich oraz zielonogórskich ${ }^{50}$.W sumie DWSPiT była przygotowana na przyjęcie nieco ponad 200 studentów. 26 października 2002 r. naukę w DWSPiT rozpoczęło 210 studentów ${ }^{51}$.

20 listopada 2006 r. odbyły się pierwsze zajęcia w ramach Polkowickiego Uniwersytetu Trzeciego Wieku. Naukę rozpoczęło ponad 100 osób. Seniorzy mogli wybrać zajęcia w blokach tematycznych: ekonomiczno-gospodarczym, humanistycznym, medyczno-psychologicznym, turystycznym, kulturalnym, informatycznym, ścisłym oraz językowym ${ }^{52}$. Obecnie na zajęcia realizowane m.in. w formie sekcji tematycznych i wykładów uczęszcza blisko 300 słuchaczy z terenu Gminy Polkowice.

W DWSPiT 28 listopada 2007 r. otwarto centrum egzaminacyjne LCCI Londyńskiej Izby Przemysłowo-Handlowej oferującej egzaminy językowe ${ }^{53}$.

\footnotetext{
44 Być może będzie wyższa uczelnia w Polkowicach, „Informator Polkowicki”, 3.07.98.

$45 \mathrm{Na}$ podst. rozmowy J. Walczaka $z$ E. Stańczysznem $z 2012 r$.

46 U. nr XI/98/99 Rady Miejskiej Polkowic z dn. 16.09.99.

47 G. Chmielowski, Czekają na ministra, „Gazeta Wrocławska”, 12.02.01.

48 M. Grohman, Minister pozwolił, „Gazeta Wrocławska”, 18.01.02.

49 A. Osadczuk, „Polkowicki Oxford”, „Gazeta Polkowicka”, nr 382001.

50 Pik, Zagłębie wyższych uczelni, „KGHM Wiadomości”, 29.01.2002.

51 Ema, Bez egzaminu, „Gazeta Wrocławska”; 20.06.02; E. Hełpa-Kulińska, Szkoła przyszłości, „Gazeta Wrocławska”,

23.10.2003.

52 Ulk, W Polkowicach ponad stu seniorów zamarzyło o indeksie, „Słowo Polskie - Gazeta Wrocławska”, 20.11.2006.

53 Jawa, Przepytaja poliglotów, „Gazeta Lubuska”, 29.11.2007.
} 
Pod koniec 2009 r. polkowicka uczelnia uzyskała Kartę Erasmusa, która upoważnia do międzynarodowej wymiany studentów oraz kadry dydaktycznej i pracowników administracji. DWSPiT podpisała umowy z uczelniami z Cypru i z Rumunii, w dalszej kolejności z uczelnią w Turcjii ${ }^{54}$. Dobrze układa się współpraca zagraniczna z uczelniami z Rosji, Ukrainy.

Rysynek 1. Logotypy: Dolnośląskiej Wyższej Szkoły Przedsiębiorczości i Techniki w Polkowicach, Polkowic oraz Polkowickiego Uniwersytetu Trzeciego Wieku.
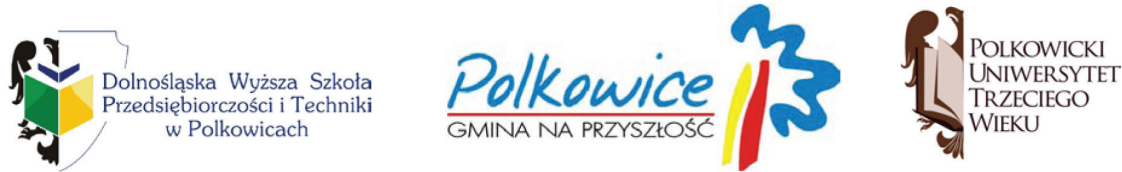

Źródło: Archiwum DWSPiT w Polkowicach. Biuro Promocji.

W sierpniu 2010 r. władze szkoły podpisały umowę na budowę nowego budynku dydaktycznego Dolnośląskiej Wyższej Szkoły Przedsiębiorczości i Techniki. Nowy, czterokondygnacyjny gmach główny zostanie połączony z dotychczasowym budynkiem uczelni ${ }^{55}$. Jego budowa zakończy się w 2013 r., a całość inwestycji zostanie sfinansowana przez Gminę Polkowice.

Obecnie szkoła kształci na czterech kierunkach w ramach studiów licencjackich i inżynierskich - stosunki międzynarodowe, administracja, mechatronika, informatyka - w trybie stacjonarnym i niestacjonarnym. W ofercie uczelni dostępne są również studia podyplomowe oraz różnorodne kursy. We wrześniu 2012 r. uczelnia uzyskała uprawnienia do prowadzenia studiów II stopnia - na poziomie magisterskim na kierunku stosunki międzynarodowe.

DWSPiT realizuje projekty współfinansowane z budżetu Unii Europejskiej w ramach Europejskiego Funduszu Społecznego. Wśród nich można wymienić zakończony już pn. „Skuteczne służby na Euro 2012" - cykl szkoleń skierowanych do policji, straży pożarnej, służby zdrowia i strażników miejskich, przygotowujący do obsługi i zapewnienia bezpieczeństwa podczas mistrzostw Europy w piłce nożnej. Inny z projektów nosi nazwę „Wzmocnienie potencjału DWSPiT w Polkowicach”. Dzięki niemu w DWSPiT organizowane są płatne staże studenckie, stworzono Biuro Karier, Klub Absolwenta, a także organizowane są zajęcia fakultatywne dla studentów z matematyki, fizyki, czy autoprezentacji56.

O uzyskanym w ciągu dekady dobrym poziomie kształcenia i oferowanej jakości świadczą rankingi szkół wyższych prowadzone przez takie czasopisma jak „Wprost”, „Perspektywy” oraz „Rzeczpospolita”. Rezultat rankingowy, będący swego rodzaju odzwierciedlaniem aktualnego wizerunku DWSPiT, z maja 2012 r. przedstawiał się następująco: DWSPiT uplasowała się w rankingu tygodnika "Wprost" na drugim miejscu na Dolnym Śląsku wśród uczelni niepublicznych, w Polsce wśród uczelni niepublicznych zajmo-

54 Abi, Żacy wyjada po wiedzę za granice Europy, „Gazeta Lubuska”, 29.01.2010.

55 Don, Powiększaja uczelnię o budynek dydaktyczny, „Gazeta Lubuska”, 25.08.2010.

$56 \mathrm{Na}$ podst. materiałów uzyskanych od DWSPiT. 
wała 29. miejsce wśród 84. notowanych. We wspólnym rankingu „Perspektyw”i „Rzeczpospolitej” uzyskała 2. pozycję na Dolnym Śląsku wśród wszystkich uczelni niepublicznych zawodowych i Państwowych Wyższych Szkół Zawodowych. 23. miejsce w Polsce wśród 72 notowanych uczelni ${ }^{57}$.

Rysunek 2. Zewnętrzna strona ulotki rekrutacyjnej DWSPiT w Polkowicach wykorzystująca pozytywny wizerunek miasta. Kampania rekrutacyjna 2010/2011.

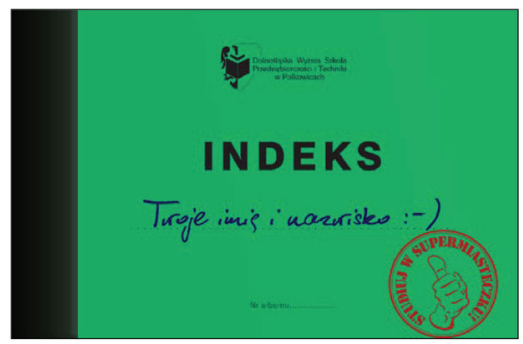

Źródło: Archiwum DWSPiT w Polkowicach. Biuro Promocji.

Rysunek 3. Zewnętrzna strona ulotki rekrutacyjnej DWSPiT w Polkowicach promująca ofertę uczelni i akademicki charakter miasta. Kampania rekrutacyjna 2012/2013.

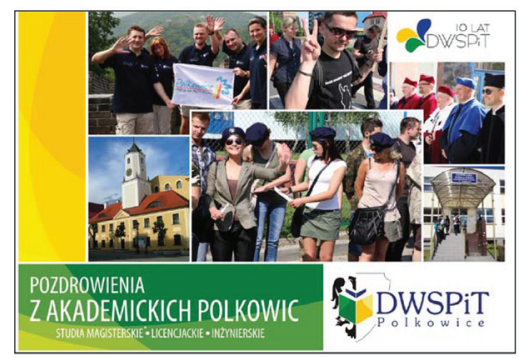

Źródło: Archiwum DWSPiT w Polkowicach. Biuro Promocji.

Polkowicka uczelnia jest inicjatorem ważnych dla regionu konferencji naukowych, począwszy od 2005 r., kiedy to zainicjowano społeczną dyskusję nad strategią Dolnego Śląska. W Polkowicach obradowano także na temat sposobów eksploatacji złóż węgla brunatnego podczas konferencji „Eksploatacja złóż nieodnawialnych w aspekcie zrównoważonego rozwoju i wymogów Unii Europejskiej” (2008). W latach 20092011 podjęto debatę dotyczącą przemian społeczności lokalnej po reformie samorządowej. W związku z tym odbyły się konferencje: „Samorząd powiatowy - doświadczenia i perspektywy rozwoju”, ,Polkowice - Dolny Śląsk - Europa”, „Przemiany społeczno-gospodarcze Polkowic po reformie samorządowej” oraz „Społeczności lokalne. Problemy - zmiany - rozwój”.

57 Rankingi szkół wyższych 2012: „Wprost”, „Perspektywy”, „Rzeczpospolita”.

Zob. http://www.perspektywy.pl/index.php?option=com_content\&task=view\&id=5077\&Itemid=926;

http://szkoly.wprost.pl/ranking/ide,27/idk,24/edycja-2012-Szkoly-niepanstwowe.html, dostęp 18.10.2012. 
Warto zaznaczyć, że nakładem wydawnictwa uczelnianego DWSPiT ukazały się dotąd m.in. tytuły, które poruszają tematykę ważną dla społeczności lokalnej:„Regionalna strategia rozwoju. Wspólne dzieło społeczności Dolnego Śląska” (2005), „Eksploatacja złóż nieodnawialnych w aspekcie zrównoważonego rozwoju i wymogów Unii Europejskiej” (2008), „Przemoc w społeczeństwie. Diagnoza, sposoby przeciwdziałania” (2008) „,Energetyka alternatywna” (2011), Polkowice w mojej pamięci” (2011) czy „Społeczności lokalne. Problemy - zmiany - rozwój" (2012).

Szczególnie ważnym wydarzeniem, które rokrocznie, odbywa się w DWSPiT, począwszy od 2009 r. jest ogólnopolskie „Forum Ekoenergetyczne” poświęcone głównie odnawialnym źródłom energii. Gościem pierwszego z Forów był przewodniczący Parlamentu Europejskiego prof. Jerzy Buzek. W roku 2012 „Forum Ekoenergetyczne” odbyło się po raz czwarty. Jego organizatorami są Fundacja na Rzecz Rozwoju Ekoenergetyki „Zielony Feniks”, Gmina Polkowice oraz DWSPiT. Aspekt dobrej współpracy w zakresie organizacji tego rodzaju wydarzeń docenia burmistrz W. Wabik:„Dbałość o dobry wizerunek jest z pewnością bardzo ważna. Gminy przykładają do tego coraz większą wagę, podobnie jak uczelnie. Wspólne udane przedsięwzięcia nazwałbym nowoczesną formułą partnerstwa, które umacnia wizerunkowo obie strony. Ukształtował się w tym zakresie trwały trend z czego jesteśmy bardzo zadowoleni"58.

DWSPiT pełni obecnie także rolę czynnika kulturotwórczego i opiniotwórczego. Pracownicy uczelni uczestniczą m.in. w pracach dotyczących budowania strategii gminy i powiatu. Ciekawą inicjatywą wykładowców i studentów była ekspedycja naukowo-badawcza „Azja 3000” do Chin i Wietnamu w 2009 r., której efektem były prelekcje, wykłady oraz wystawa fotograficzna. Również studenci aktywnie uczestniczą w życiu miasta, organizując działania o charakterze sportowym, charytatywnym czy edukacyjnym. Najistotniejszym wydarzeniem kulturalnym, które jest związane z życiem miasta są Dewuspitalia, czyli święto polkowickich studentów ${ }^{59}$.

\section{Wspólne korzyści pozytywnego wizerunku}

Utworzenie uczelni w Polkowicach wpisuje się w politykę proedukacyjną samorządu lokalnego i domyka system kształcenia w subregionie polkowickim m.in. poprzez funkcjonowanie studiów licencjackich, magisterskich, podyplomowych, jak również Polkowickiego Uniwersytetu Trzeciego Wieku, dzięki czemu możliwe jest kształcenie członków społeczności lokalnej w różnym wieku (koncepcja Life Long Learning uczenia się przez całe życie). Jak zaznacza burmistrz W. Wabik: „Wydatkowanie środków publicznych na edukację i naukę ma głęboki sens. To jedna z tych inwestycji, które zapewniają satysfakcjonujący zwrot, gdyż podnoszą jakość życia mieszkańców, zarówno doraźnie, jak i w dłuższej perspektywie. Gmina wspierając uczelnię po prostu wypełnia swoją powinność, szczególnie w sytuacji, gdy tak jak w Polkowicach, rozwojowe cele są przez lokalną wspólnotę w pełni uświadamiane i akceptowane"60.

58 Rozmowa z burmistrzem Polkowic W. Wabikiem przeprowadzona przez J. Walczaka $w 2012$ r. 59 W. Olszewski, W poszukiwaniu modelu uczelni lokalnej, [w:] M. Adamczyk, A. Chmiel, Społeczności lokalne. Problemy-zmiany-rozwój, Polkowice 2012, s. 60-61. Zob. też A. Marszałek, Rola uczelni w regionie, Warszawa 2010, s. 202. 60 Rozmowa z burmistrzem W. Wabikiem przeprowadzona przez J. Walczaka w 2012 r. 
W. Olszewski, w artykule pt.„W poszukiwaniu modelu uczelni lokalnej” przywołuje opinię A. Marszałka, który uważa, że pewne obszary posiadają specyficzne uwarunkowania, pozwalające na zakwalifikowanie ich do regionów uczących się. Owe uwarunkowania to m.in. odpowiednie zlokalizowanie uczelni lub jednostki badawczej, występowanie dużej ilości przedsiębiorstw prowadzących działalność innowacyjną, opartych na nowoczesnych technologiach i zarządzaniu, wspieranie przez samorząd inicjatyw edukacyjnych dla społeczności lokalnej w ramach wspomnianego modelu kształcenia się przez całe życie. Zdaniem W. Olszewskiego Gmina Polkowice jest „regionem uczącym się” i dysponuje postawionymi przez A. Marszałka uwarunkowaniami. Kluczowym elementem takiego regionu jest istnienie uczelni, odgrywającej istotną rolę, stanowiącej centrum różnorakiej działalności, jako kreator działań edukacyjnych, innowacyjnych, doradczych, a jednocześnie będącej ważnym partnerem dla samorządu terytorialnego w procesie rozwoju subregionu, na terenie którego jest zlokalizowana. Co więcej, władze DWSPiT w Polkowicach podejmują próbę wykreowania nowego wizerunku instytucji kształcenia na poziomie wyższym - czyli „uczelni samorządowej”, działającej na rzecz społeczności lokalnej i współfinansowanej przez samorząd ${ }^{61}$. To ciekawe rozwiązanie, ponieważ polskie prawo dotyczące szkolnictwa wyższego przewiduje dychotomiczny podział na uczelnie publiczne i niepubliczne (prywatne). Model uczelni samorządowej w dużej mierze współfinansowany z budżetu jednostki samorządu terytorialnego jest unikalny w skali kraju, jednocześnie na tyle ciekawy i ważny dla rozwoju społeczności lokalnej, że wart naśladowania. Poprzez wzajemną koegzystencję w takiej formie zarówno uczelnia, jak i polkowicki samorząd wzmacniają wzajemny wizerunek.

Rysunek 4. Projekt baneru reklamowego z hasłem wykorzystującym pozytywny wizerunek Polkowic.

Kampania rekrutacyjna 2010/2011.

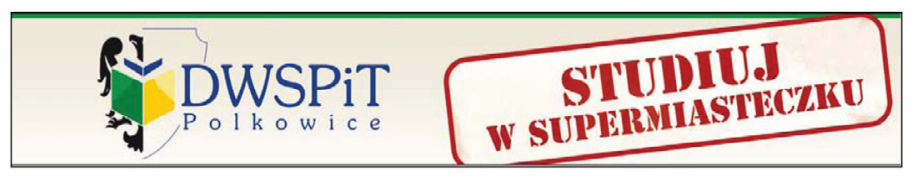

Źródło: Archiwum DWSPiT w Polkowicach. Biuro Promocji.

Obu uczestnikom relacji zależy na budowaniu jak najsilniejszych więzi i działaniu dla wspólnego dobra, co dotyczy nie tylko władz samorządowych, ale także całej społeczności lokalnej subregionu polkowickiego, która coraz silniej utożsamia się ze „swoją” szkołą wyższą - dostępną, będącą w zasięgu ręki. Pośród czynników wpływających na wybór szkoły wyższej można wymieniać m.in: tematykę studiów, motywy ekonomiczne, charakter uczelni (publiczna lub niepubliczna), warunki rekrutacji, jakość kształcenia czy właśnie dogodne położenie. To ostatnie kryterium zdaniem A. Kuliga i G. Nowaczyk - na które zwracało uwagę 24 proc. badanych - może mieć znaczenie wspomagające ostateczny wybór studiów. Położenie uczelni wiąże się bowiem z koniecznością dojazdów, często też z potrzebą zamieszkania w ośrodku

61 W. Olszewski, W poszukiwaniu modelu..., op.cit., s. 57. 
akademickim. Okazuje się zatem, że lokalizacja uczelni ważniejsza jest dla badanych niż pozycja uczelni w rankingach, opinia znajomych czy nawet prestiż ${ }^{62}$.

Aspekt akademickości oraz posiadania na swoim terenie szkoły wyższej, a co za tym idzie kapitału intelektualnego nie jest naturalnie jedynym i najważniejszym elementem, pozwalającym na kreowanie pozytywnego wizerunku samorządu lokalnego Polkowic. Jednak w zestawieniu z innymi samorządami wyróżnia Gminę Polkowice. Nie do końca nawet poprzez sam fakt działania szkoły wyższej na terytorium, gdyż szkoły wyższe funkcjonują m.in. w Głogowie, Lubinie i Legnicy, ale poprzez szczególne zaangażowanie samorządu w rozwój uczelni, wzajemne ponadstandardowe relacje na linii samorząd - uczelnia. Tak współpracę określa burmistrz Polkowic: „Ocena jest bardzo pozytywna. Jednocześnie mam świadomość, jak dużym potencjałem dysponuje DWSPiT w Polkowicach i że te możliwości warto wykorzystać dla dobra miasta i gminy. Sporo będzie tu jednak zależało od nas samorządowców. Musimy poszukiwać nowych płaszczyzn współpracy, realistycznie lecz także atrakcyjnie formułować cele".

Rola jaką odgrywa DWSPiT w regionie i na rzecz społeczności lokalnej Polkowic pokrywa się z trzynastoma funkcjami społeczno-edukacyjnymi uczelni niepublicznych wymienianymi przez T. i Z. Kruszewskich przywołanymi i omówionymi szerzej w odniesieniu do polkowickiej uczelni przez W. Olszewskiego ${ }^{63}$. W tym miejscu zostaną one jedynie przywołane, aby zobrazować rolę DWSPiT, a należą do nich: 1) wzbogacenie sieci szkolnej i umożliwienie młodzieży podejmowania studiów w większej grupie niż dotychczas; 2) zmiana struktury pochodzenia studentów; 3) rozwinięcie systemu studiów zaocznych i wieczorowych; 4) szkoły niepaństwowe nie odciągają studentów i absolwentów z terenu małej ojczyzny; 5) szkoła niepaństwowa w środowisku lokalnym pomaga nie tylko ukończyć studia, ale także wyłania talenty naukowe; 6) tworzenie środowiska naukowego w mieście i regionie; 7) oddziaływanie kulturowe na środowisko lokalne; 8) tworzenie nowych miejsc pracy; 9) relacje między studentami a młodzieżą żyjącą w danym środowisku; 10) kształcenie otwarte na kształcenie w regionie; 11) propagowanie i realizacja kształcenia licencjackiego; 12) wprowadzanie i upowszechnianie nowych form pracy; 13) wytworzenie nowego typu relacji między nauczycielami a słuchaczami ${ }^{64}$.

62 A. Kulig, G. Nowaczyk, Decyzje maturzystów o wyborze uczelni i ich determinanty, [w:] G. Nowaczyk, M. Kolasiński, Marketing szkół wyższych, Poznań 2004, s. 155.

63 W. Olszewski, W poszukiwaniu..., op. cit., s. 57-64.

64 W. Olszewski, Miejsce..., op. cit., s. 75, za: Z. Kruszewski, T. Kruszewski, Rola niepaństwowej uczelni, op. cit., s. $296-300$. 
Rysunek 5. Relacje między samorządem terytorialnym w Polkowicach a DWSPiT - zarys modelu.

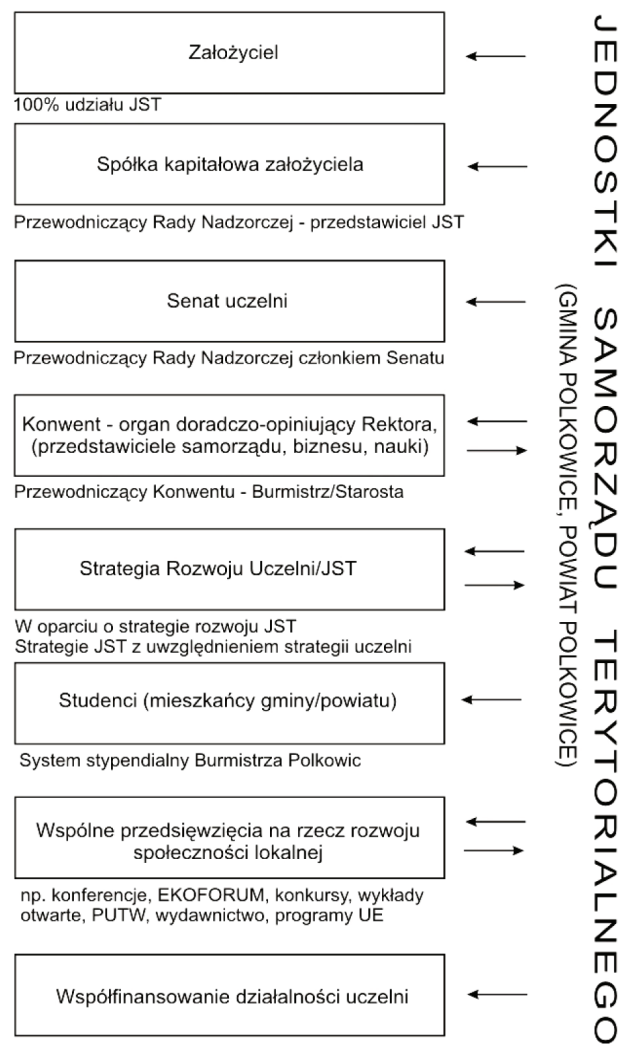

Źródło: W. Olszewski, W poszukiwaniu modelu uczelni lokalnej, [w:] Społeczności lokalne. Problemy - zmiany rozwój, praca zbiorowa pod red. M. Adamczyka, A. Chmiela, Polkowice 2012, s. 65.

Z kolei H. Bednarski o funkcjach uczelni ważnych dla społeczności lokalnej pisze: „,szkoły wyższe spełniają niezwykle ważne funkcje kulturotwórcze i miastotwórcze w środowisku lokalnym, w którym działają. Wyraża się to między innymi w aktywizacji kulturalnej środowisk lokalnych, w rozszerzaniu oferty edukacyjnej, w tworzeniu nowych miejsc pracy, w promocji miast i szerszych regionów, w których zlokalizowane są szkoły wyższe ${ }^{\prime \prime 65}$. Wymienione funkcje społeczno-edukacyjne uczelni pozwalają na wzmacnianie potencjału samorządu lokalnego i przyczyniają się to stabilizacji i rozwoju jego tożsamości, a w konsekwencji kształtowania ważnego segmentu wizerunkowego.

Samo powołanie uczelni w Polkowicach z inicjatywy samorządu wiązało się z koniecznością zabezpieczenia regionowi wysoko wykwalifikowanych kadr na potrzeby rozwijającej się polkowickiej części Legnickiej Specjalnej Strefy Ekonomicznej. Działający tam przemysł motoryzacyjny związany z produkcją

65 H. Bednarski, Kulturotwórcze funkcje szkoły wyższej w środowisku lokalnym, [w:] Poszukiwanie modelu wyższej szkoły niepaństwowej, praca zbiorowa pod red. M. Dudka, Legnica 2003, s. 303. 
silników Diesla, siedzeń samochodowych, klimatyzatorów oraz branża obuwnicza i inne wymagają obsługi technologicznej przez wysoko wykwalifikowanych specjalistów. Odpowiedzią na zapotrzebowanie lokalnego rynku pracy w pewnym zakresie są oferowane przez DWSPiT kierunki studiów: mechatronika, informatyka ale także stosunki międzynarodowe i administracja. Dostosowaniu programu nauczania do bieżących, realnych potrzeb pracodawców na poszczególnych kierunkach studiów służą konsultacje prowadzone między władzami DWSPiT a Konwentem Uczelni zrzeszającym przedstawicieli znaczących firm oraz instytucji w regionie, również samorządowców. Konwentowi przewodniczy burmistrz Polkowic.

Przewodnictwo burmistrza w Konwencie uczelni sprzyja wizerunkowi gminy jako samorządu kompetentnego, troszczącego się o wykształcenie społeczności lokalnej, tworzącego sprzyjający klimat do działania biznesowego. Dodatkowo zacieśnianie współpracy uczelni i samorządu jest wsparciem autorytetu władz gminy. Prowadzone w DWSPiT w ostatnich latach badania w dziewięciu zespołach naukowych dotyczące rozwoju Polkowic po 1990 r. są finansowane w pełni przez samorząd. Efektem prac będzie dziewięć tomów monografii poświęconych przemianom społeczno-gospodarczym. Zobrazują one i udokumentują obecny stan rozwoju Polkowic. Tego rodzaju przedsięwzięcie jest unikalne w skali kraju. W realizacje projektu zaangażowani zostali naukowcy z DWSPiT a także największych wrocławskich uczelni m.in. Uniwersytetu Wrocławskiego, Politechniki Wrocławskiej czy Uniwersytetu Ekonomicznego.

W chwili obecnej DWSPiT jest rozwijającą się, nowoczesną szkołą wyższą, w której studiuje blisko 500 studentów z regionu. Rekrutacja od kilku lat kształtuje się na podobnym poziomie 150-200 osób. Zajęcia odbywają się w małych, kameralnych grupach, umożliwiających łatwy dostęp do wykładowców. Pochodzą oni głównie z uczelni wrocławskich, ale w ostatnich latach intensywnie rozwija się kadra miejscowa. Co więcej, czesne należy do najniższych w kraju, natomiast pierwszy rok studiów dziennych jest nieodpłatny. Uczelnia oferuje studentom bogaty system stypendialny, obejmujący m.in. stypendium burmistrza Polkowic za najwyższą średnią ocen.

Pozytywny wizerunek uczelni dla władz Polkowic to wyznacznik miasta nowoczesnego, którego rozwój opiera się również na wiedzy. Uczelnia daje szansę zatrzymania młodzieży w mieście, dotąd wyjeżdżającej na naukę do dużych ośrodków akademickich i niejednokrotnie pozostających tam na stałe. Polkowice charakteryzują się jedną z najniższych stóp bezrobocia na Dolnym Śląsku (kwiecień 2012 r. - 9,5 proc.), co w zestawieniu z mocną stroną gospodarczą i socjalną gminy, dobrze rozwiniętą ofertą edukacyjną tworzy wizerunek miejsca dobrego do życia ${ }^{66}$.

Gmina Polkowice jest przywoływana dziś jako przykład zastosowania udanych strategii marketingowych i niekwestionowanego sukcesu w podejmowaniu działań marketingu terytorialnego ${ }^{67}$, o czym świadczą pozyskani inwestorzy krajowi i zagraniczni a także stosunkowo duża rozpoznawalność marki Polkowic w regionie i w kraju.

DWSPiT w działaniach marketingowych od kilku lat wykorzystuje pozytywny wizerunek samorządu, na terenie którego funkcjonuje, nie tylko ze względów kurtuazyjnych wobec fundatora, ale przede wszystkim z powodów pragmatycznych. Bowiem zestawienie marki Polkowic z marką uczelni pozwala na pobudze- 
nie pozytywnych skojarzeń z takimi hasłami jak: praca, strefa ekonomiczna, Aquapark, rozpoznawane w kraju kluby sportowe.

W kolejnych kampaniach promocyjnych DWSPiT oferta edukacyjna promowana była poprzez hasła: "Supermiasteczko-Superuczelnia”, ,Studiuj w Supermiasteczku” czy „Pozdrowienia z akademickich Polkowic". Świadczą one o jednoczesnym promowaniu uczelni i jej otoczenia z wykorzystaniem pozytywnego wizerunku Polkowic i swego rodzaju „ogrzewaniu się" marki uczelni w ich blasku. Jednak z drugiej strony Gmina Polkowice także odnosi realne korzyści wizerunkowe.

Polkowicka uczelnia przyciąga studentów zapewne i z tego powodu, że nie jest bezwzględnie nastawiona na zysk a przede wszystkim na osiąganie konkretnych wymiernych efektów działalności i kształcenia. Dotacje gminne pozwalają na zapewnienie płynności finansowej DWSPiT, co sprzyja możliwości tworzenia produktu edukacyjnego najwyższej jakości, który przekłada się na zadowolenie studentów i renomę szkoły lokującej się na dobrej pozycji na rynku edukacyjnym.

Dla podsumowania warto wyznaczyć najistotniejsze, zdaniem autora, czynniki wpływające na udział DWSPiT we wzmacnianiu wizerunku Gminy Polkowice, z drugiej zaś strony ważne czynniki wpływające na udział Gminy Polkowice we wzmacnianiu wizerunku polkowickiej uczelni. Pozwoli to na zarysowanie obrazu wspólnych korzyści wizerunkowych, wynikających z trwającej dekadę współpracy.

Udział DWSPiT we wzmacnianiu wizerunku Gminy Polkowice:

- Możliwość kształcenia na wielu szczeblach edukacji w Gminie Polkowice po utworzeniu w 2002 r. DWSPiT. Obok żłobka, przedszkoli, szkół podstawowych, gimnazjów, szkoły ponadgimnazjalnej funkcjonuje także szkoła wyższa, oferująca: studia licencjackie, inżynierskie, magisterskie (stacjonarne i niestacjonarne), podyplomowe, Uniwersytet Trzeciego Wieku, a także kursy i szkolenia. W praktyce realizowany jest model kształcenia przez całe życie (LLL), który jest podstawą tworzenia nowoczesnych społeczności „uczących się".

- Rozwinięcie oferty skierowanej do inwestorów poprzez zapewnienie na terenie Gminy Polkowice wykwalifikowanych kadr - mechatroników, informatyków, pracowników biurowych, specjalistów w zakresie stosunków międzynarodowych m.in. na potrzeby polkowickiej podstrefy Legnickiej Specjalnej Strefy Ekonomicznej SA. Dodatkowo stały kontakt przedstawicieli uczelni, władz samorządowych oraz przedstawicieli biznesu zapewnia Konwent Uczelni, działający przy DWSPiT jako organ doradczy Rektora.

- Ukazywanie przemian i rozwoju Gminy Polkowice w ostatnich dwóch dekadach poprzez badania naukowe prowadzone w DWSPiT. Wyniki prac dziewięciu zespołów zostaną opublikowane w 2012 r. w monografiach przygotowywanych obecnie do druku. Wspólne organizowanie przez DWSPiT oraz Gminę Polkowice konferencji naukowych poświęconych samorządowi i społecznościom lokalnym. Towarzyszące im publikacje tematyczne wydawane przez Wydawnictwo DWSPiT, są równie ważne dla pozytywnego postrzegania samorządu Polkowic.

- Rozwój kapitału społeczno-intelektulanego miasta. Tworzenie środowiska naukowego w mieście i regionie. Szansa na osiedlanie się na stałe absolwentów DWSPiT i osób związanych z funkcjonowaniem 
uczelni. Uczelnia staje się czynnikiem miastotwórczym.

- Prestiż dla 26-tysięcznej gminy wynikający z posiadania szkoły wyższej. Szczególnie silny i wieloaspektowy związek gminy z uczelnią wyróżnia Polkowice na tle innych samorządów, które również na swoim terytorium posiadają szkoły wyższe (m.in.: Legnica, Lubin, Głogów, Leszno).

- Aktywizacja społeczności lokalnej poprzez ofertę kulturalno-edukacyjna DWSPiT m.in. w ramach Polkowickiego Uniwersytetu Trzeciego Wieku, Festiwalu Nauki, wykładów popularnonaukowych, święta polkowickich studentów pn. Dewuspitalia, konkursów, zawodów, spotkań autorskich ze znanymi osobami i okolicznościowych wydarzeń itp.

- Promocja gminy przez DWSPiT podczas targów edukacyjnych, spotkań naukowych, konferencji, forów, wyjazdów promocyjnych uczelni do szkół ponadgimnazjalnych, poprzez stronę www, rozpowszechnianie logotypu Polkowic na materiałach promocyjnych uczelni, itp.

Udział Gminy Polkowice we wzmacnianiu wizerunku DWSPiT:

- Uczelnia elementem strategii rozwoju zrównoważonego Gminy Polkowice. Dzięki temu możliwy jest stabilny i zaplanowany rozwój DWSPiT. Obecnie trwa budowa nowego gmachu głównego uczelni w całości finansowana z budżetu Gminy Polkowice. Zgodnie ze „Strategią Rozwoju Zrównoważonego Gminy Polkowice na lata 2010-2015" rozwój alternatywnych form działalności gospodarczej wobec KGHM Polska Miedź SA będzie dotyczył przede wszystkim przemysłu, budownictwa, handlu i usług. Nie bez znaczenia pozostaną szkolnictwo, nauka, rolnictwo i usługi niekomercyjne.

- Promocja uczelni przez Gminę Polkowice na szerokim forum (m.in. foldery, targi, spotkania). Samorząd promując subprodukty terytorialne, w tym oświatowo-społeczny, przyczynia się także do promocji DWSPiT, która jako uczelnia założona przez samorząd i współfinansowana z jego budżetu stanowi ważny i pozytywnie wyróżniający się w skali ogólnopolskiej produkt zaspokajający ważne potrzeby społeczności lokalnej.

- Uczelnia realizuje zlecone przez samorząd projekty istotne dla społeczności lokalnej Polkowic: badania, konferencje poświęcone samorządowi lokalnemu, szkolenia. Funkcjonuje Polkowicki Uniwersytet Trzeciego Wieku (ok. 300 słuchaczy), wydawnictwo uczelniane (m.in. wydany tom pokonkursowy wspomnień „Polkowice w mojej pamięci”). Dzięki temu DWSPiT może być postrzegana jako uczelnia społecznie użyteczna, a wręcz jako dobro wspólne ponad istniejącymi podziałami w różnych kwestiach.

- Pozytywny wizerunek gminy może mieć wpływ na wybór studiów w Polkowicach - atrakcyjne miasto z ciekawą ofertą socjalną, kulturalną, gospodarczą może przekonać niezdecydowanych kandydatów do studiowania właśnie tutaj.

- Satysfakcja studentów z wysokiej jakości kształcenia. Zysk nie zawsze musi być priorytetem. Jest to możliwe w wyniku ekonomicznego wsparcia przez samorząd lokalny. W efekcie DWSPiT proponuje studentom: pierwszy rok studiów dziennych nieodpłatny dla wszystkich, czesne za semestr należące do najniższych w Polsce, bogatą ofertę stypendialną. 


\section{Podsumowanie}

Pozytywny wizerunek samorządu i uczelni, jest wspólnym interesem, sprzyja rozwojowi specyficznej uczelni, którą można by nazwać „uczelnią samorządową", będącą dobrem wspólnym „małej ojczyzny", gdzie nie tylko kształci się studentów, ale także są inicjowane przedsięwzięcia prorozwojowe, dla i z udziałem samorządu lokalnego, mającego rzeczywisty wpływ na swoją uczelnię i własny wizerunek, zaś partnerski model „uczelni samorządowej" można potraktować jako alternatywę wobec dychotomicznego podziału na uczelnie publiczne i niepubliczne ${ }^{68}$. Wspieranie wzajemnego wizerunku wydaje się zatem koniecznością.

Przytoczone, wybrane przykłady aktywności samorządu-założyciela uczelni we współpracy z DWSPiT mogą świadczyć o dużym zaangażowaniu władz Polkowic i woli podejmowania działań wraz z uczelnią, promowaniu się poprzez naukę i inicjatywy organizowane na arenie regionalnej, a także ogólnopolskiej (Forum Ekoenergetyczne). Korzyści ze współpracy są obopólne. Gmina, na terenie której znajduje się współfinansowana przez nią uczelnia, podnosi własne znaczenie wizerunkowe, z kolei uczelnia, utrzymująca wysoki poziom współpracy z samorządem, zaangażowana w jego sprawy buduje swój wizerunek na solidnych podwalinach akceptacji i więzi z władzami lokalnymi, wpisując się w tożsamość mieszkańców miasta, gminy, powiatu i regionu. Dostrzegają oni bowiem praktyczny wymiar uczelni w ich sąsiedztwie a jej obecność staje się czymś zupełnie naturalnym, zatem łatwo podjąć decyzję o skorzystaniu z jej usług.

Współdziałanie pozwala na wzajemną promocję i budowanie silnej pozycji wizerunkowej zarówno uczelni na tle mocnej, nowoczesnej prężnie rozwijającej się m.in. gospodarczo gminy jak i gminy na tle uczelni - wizerunek miasta akademickiego, rozwijającego się ośrodka akademickiego, pełnego aktywnych osób. Daje to efekt, dzięki któremu wykreowuje się Supermiasteczko z Superuczelnią - miejsce gdzie chce się studiować, mieszkać i pracować. Co ważne burmistrz Polkowic widzi tę współpracę w perspektywie: "(...) za 10-20 lat nasza uczelnia będzie nadal źródłem wielu społecznych pożytków, intelektualnym centrum, korzystną inspiracją do zdobywania i uzupełniania wiedzy przez dorosłych w bardzo różnym wieku", zaś w kwestii budowania wspólnego pozytywnego wizerunku uczelni i samorządu podkreśla, że „mamy do czynienia ze wspólną sprawą i dlatego musimy wszystkim najistotniejszym zadaniom skutecznie sprostać. Wszystko wskazuje na to, iż pod tym względem jesteśmy na dobrej drodze".

\section{Bibliografia}

1. Abi, Żacy wyjadą po wiedzę za granice Europy, „'Gazeta Lubuska”, 29.01.10,

2. Badanie opinii mieszkańców Gminy Polkowice. Raport z badania ilościowego zrealizowanego na zlecenie Urzędu Gminy Polkowice. Opracowanie: Biuro Badań Społecznych Obserwator, wrzesień 2009,

3. Bednarski H., Kulturotwórcze funkcje szkoły wyższej w środowisku lokalnym, [w:] M. Dudek (red.), Poszukiwanie modelu wyższej szkoły niepaństwowej, Legnica 2003,

4. Być może będzie wyższa uczelnia w Polkowicach, „Informator Polkowicki”, 3.07.1998,

5. Cenker E. M., Public relations, Poznań 2007,

68 W. Olszewski, W poszukiwaniu..., op. cit., s. 64-66. 
6. Chmielowski G., Czekają na ministra „ "Gazeta Wrocławska”, 12.02.01,

7. Don, Powiększają uczelnię o budynek dydaktyczny ,"Gazeta Lubuska”, 25.08.10,

8. Ema, Bez egzaminu, "Gazeta Wrocławska”, 20.06.02,

9. Goban Klas T., Public relations czyli promocja reputacji, Warszawa 1997,

10. Grohman M., Minister pozwolił, „Gazeta Wrocławska”, 18.01.02,

11. Hełpa-Kulińska E., Szkoła przyszłości, „Gazeta Wrocławska”, 23.10.03,

12. Iwankiewicz-Rak B., Public relations w instytucjach publicznych i organizacjach pozarządowych, [w:] J. Olędzki, D. Tworzydło (red.) Public relations. Znaczenie społeczne i kierunki rozwoju, Warszawa 2007,

13. Iwankiewicz-Rak B., Zarządzanie marketingowe szkołą wyższą, [w:] G. Nowaczyk, M. Kolasiński (red.) Marketing szkół wyższych, Poznań 2004,

14. Jawa, Przepytają poliglotów, „Gazeta Lubuska”, 29.11.07,

15. Kłeczek R., Kowal W., Woźniczka J., Strategiczne planowanie marketingowe, Warszawa 1999,

16. Kulig A., Nowaczyk G., Decyzje maturzystów o wyborze uczelni i ich determinanty, [w:] G. Nowaczyk, M. Kolasiński, Marketing szkół wyższych, Poznań 2004,

17. Markowski T., Zarządzanie rozwojem miast, Warszawa 1999,

18. Marszałek A., Rola uczelni w regionie, Warszawa 2010,

19. Niewiadomski Z. (red.), Samorząd terytorialny. Ustrój i gospodarka, Bydgoszcz-Warszawa 2001.

20. Olszewski W., Miejsce niepublicznej szkoły wyższej w rozwoju społeczności lokalnej polskich Łużyc, [w:] M. Adamczyk, T. Chmiel (red.), Lokalne problemy edukacyjne w perspektywie kształcenia w szkołach wyższych, Legnica 2011,

21. Olszewski W., W poszukiwaniu modelu uczelni lokalnej - studium przypadku, [w:] M. Adamczyk, A. Chmiel, Społeczności lokalne. Problemy, zmiany, rozwój, Polkowice 2012,

22. Osadczuk A., Polkowicki Oxford, „GP", nr 38/2001,

23. Pik, Zagłębie wyższych uczelni, „KGHM Wiadomości”, 29.01.02,

24. Rozmowa z aktualnym burmistrzem Polkowic Emilianem Stańczysznem przeprowadzona przez Jana Walczaka w 2012 r.,

25. Rozmowa z byłym burmistrzem Polkowic Emilianem Stańczysznem przeprowadzona przez Jana Walczaka w 2012 r.,

26. Rozmowa z ostatnim naczelnikiem Polkowic przed 1990 r. Bolesławem Kocwą przeprowadzona przez Jana Walczaka w 2011 r.,

27. Rozmowy z mieszkańcami Polkowic zostały przeprowadzone przez J. Walczaka w 2011 i 2012 r. na potrzeby monografii: J. Tyszkiewicz, J. Walczak, Polkowice - historia współczesna (1945-2010), Polkowice 2012 r. Archiwum autora,

28. Stanowicka-Traczyk A., Kształtowanie wizerunku miasta na przykładzie miast polskich, BydgoszczOlsztyn 2008,

29. Sztando A., Strategia rozwoju zrównoważonego Gminy Polkowice na lata 2010-2015, Polkowice 2010, 
30. Szydłowska-Szczecińska A., Polkowice. Dwadzieścia niezwykłych lat, Żary 2010,

31. Ulk, W Polkowicach ponad stu seniorów zamarzyło o indeksie, „Słowo Polskie - Gazeta Wrocławska”, 20.11.06,

32. Wyniki konkursu na wiersz o Polkowicach, ,"Gazeta Polkowicka”, czerwiec - lipiec 1991, nr 6-7/9-10,

33. Zeman-Miszewska Z., Kreowanie konkurencyjności i regionów przez samorządy terytorialne, [w:] H. Szulce, M. Florek (red.), Marketing terytorialny: możliwości aplikacji, kierunki rozwoju, Poznań 2005.

\section{Akty prawne}

- Uchwała Rady Miejskiej w Głogowie nr VI/26/2011 z dnia 13 stycznia 2011 r. w sprawie budżetu Gminy Miejskiej Głogów na rok 2011,

- Uchwała Rady Miejskiej w Lubinie nr IV/24/11 z dnia 11 stycznia 2011 r. w sprawie budżetu miasta Lubina na rok 2011,

- Uchwała Rady Miejskiej w Polkowicach nr Vl/47/11 z dnia 3 lutego 2011 r. w sprawie budżetu gminy na rok 2011,

- Ustawa o samorządzie gminnym z dnia 8 marca 1990 r., Dz. U. 2001.142.1591.

\section{Strony internetowe}

- 5 pytań do Małgorzaty Skórskiej i Jana Wawrzyniaka dbających o wizerunek Gminy Polkowice, http://www.proto.pl/archiwum/5pytan2/info?trackName=PR_5pytan_question\&maxrec=30\&type_ $\mathrm{id}=$ eq\&id=25, dostęp 10.10.2012,

- http://szkoly.wprost.pl/ranking/ide,27/idk,24/edycja-2012-Szkoly-niepanstwowe.html,dostęp 18.10.2012,

- Marketing terytorialny, http://bajorconsulting.pl/marketing-terytorialny/, dostęp 2.10.2012,

- Mat, Kasa pęka w szwach, Radio Elka Głogów-Lubin-Polkowice-Legnica, 3.10.2012, http://miedziowe. $\mathrm{pl} /$ content/view/59511/81/, dostęp 2.10.2012,

- Nagrody przyznane dla Gminy Polkowice, http://www.polkowice.pl/strona/39/Sukcesy\%20 gminy\%20Polkowice, dostęp 4.10.2012,

- Rankingi szkół wyższych 2012: „Wprost" ,„Perspektywy”, „Rzeczpospolita”. Zob. http://www.perspektywy.pl/index.php?option=com_content\&task=view\&id=5077\&ltemid=926,

- Urząd Pracy w Polkowicach, Stopy bezrobocia-zestawienie, http://www.pup.polkowice.one.pl/pupp/ index.php?idCat=5, dostęp 18.10.2012,

- Włóczyk P., Rajskie życie w bogatych gminach, Prawo-Rzeczpospolita, 27.07.2011 http://prawo.rp.pl/ artykul/693309.html, dostęp 18.10.2012. 